\title{
Seed Systems in the Four Shallot Producing Areas of Java: A Focus Group Discussion
}

\author{
Witono Adiyoga ${ }^{1, *}$ \\ ${ }^{1}$ Indonesian Vegetable Research Institute, Jl. Tangkuban Perahu 517, Lembang, Bandung - 40391, \\ West Java, Indonesia.
}

\begin{abstract}
Understanding shallot seed systems is crucial for managing crop biodiversity on-farm where it is of both private value to farmers and social significance for future crop improvement and the resilience of the farming system. Focus Group Discussion (FGD) was carried out in Cirebon-West Java, Brebes-Central Java, Bantul-Yogyakarta S.R and Nganjuk-East Java. In Java, FGDs estimate that the share of formal seed sector in the total shallot seed supply rarely exceeds $5 \%$. Hence, the seed supply is heavily relied on the informal seed system in which farmers use their-own strategies, including farmer-saved seeds, farmer seed exchange, and farmer-managed seed production. In the meantime, FGDs indicate that both systems in general are still characterized by low quality seeds, limited clean/healthy seeds, lack of supporting qualified human resources, lack of supporting infra-structure, and low transfer of seed technology. Both systems actually have considerable strengths to be leveraged and weaknesses to be improved. Therefore, FGDs suggest that integrating and recognizing the coexistence of the formal and informal seed systems in the four shallot producing areas in Java should be embraced to optimize the mutual benefits between the two systems.
\end{abstract}

\section{Introduction}

In Indonesia, shallot is a prominent economic crop grown year-round mostly in lowlands by nearly a million of small-scale farmers. Yearly demand for shallot is relatively stable, but the market supply is quite volatile. Therefore, any sharp increase (or decline) in crop price, or any sharp change in supply level will generate a market disturbance, even contribute to economic inflation. Another issue that has long been a concern is the wide gap between actual yield (9-12 $\mathrm{t} / \mathrm{ha}$ ) and potential yield (15-20 t/ha). In general, the most critical factor limiting shallot yield in Indonesia is the rare availability of good quality seeds or not fully yet developed seed systems [1].

Seed plays very important role in an effort of improving crop production and increasing crop yield. The efficacy of other production inputs will be depended on the seed, so that however much a farmer puts to use other productive inputs (land, fertilizer, labor, etc.), an output realization will still be determined by the seed. Seed is considered as an integral part of agriculture since it provides the maximum limit of crop yield of all other production inputs $[2,3,4]$. In shallot particularly, the seed is considered as a very significant input since farmers have to invest about $25-50 \%$ of total cost to acquire it $[5,6]$.

The genetic makeup of seed has been widely known as an important factor that determines the crop yield potential and stability [7]. As a catalyst in agricultural production [8], quality seed

\footnotetext{
${ }^{*}$ Corresponding author: adiyogawitono@gmail.com
} 
is a critical component in ensuring the success of development strategy for improved agricultural production and productivity, food security and livelihoods $[9,10,11]$. Good quality seeds are those that satisfy appropriate genetic, physical, health standards, germination and moisture percentage and vigor requirements for achieving higher yield $[12,13]$. When farmers use bad quality seeds, then all of their investments for other inputs will most likely turn to waste $[14,15]$.

As far as seeds are concerned, two key issues confronted by every farmer are seed availability and quality. Ideally, appropriate quantities, qualities and price affordability of seeds should be met by farmers when they need them $[16,17,18]$. In developing countries, ever since seed is considered as a crucial input for improving cultivation techniques and increasing crop production, the seed supply systems have received considerable attention. It should be noted that to have the use of quality seeds and to make them available need a process. Continuous development of new and improved crop varieties and efficient production and supply systems of seeds to farmers are requirements for having sustained increase in agriculture production and productivity $[19,20$, 21].

Despite its crucial importance in shallot production, the body of knowledge regarding shallot seed system in Indonesia is still scanty. This paper therefore seeks to provide an overview and to assess the current shallot seed systems operating in Java, and to identify overall possible improvements.

\section{Materials and Methods}

Focus Group Discussion - FGD (an interactive discussion of participants who have similar background and experience to discuss a specific topic of interest) was selected as data collection method. [22, 23]. FGD is an organized discussion involves selected relevant participants in gathering in-depth information of specific research topic based on their attitude, belief, opinion and experiences $[24,25,26]$.

Focus group discussion was carried out in each of the four study sites (Cirebon-West Java, Brebes-Central Java, Bantul-Yogyakarta S.R and Nganjuk-East Java). The facilitator used a discussion guide that served as a roadmap to keep the session on track in covering the listed topics, while allowing participants to talk freely and spontaneously. The number of items in the guide was kept to a minimum (such as, shallot varieties mostly preferred, regional seed need and availability, access to good quality seeds, source of seeds, seed distribution, challenges to improve the seed systems), to leave enough time for in- depth discussion.

Participants were recruited through a consultation with the District Agricultural Office-DAO (Dinas Pertanian Kabupaten) and purposively selected, since FGD was intended to gain insights of participants' shared understanding with regards to shallot seed systems in each study site [27]. In this study, 14-15 persons were invited in each FGD, since the purpose is to generate depth of expression from participants. The composition of the group was set up to be aligned with the main topic of the study $[28,29]$, i.e. seed systems. The group was consisted of farmers (seed users), seed growers, seed traders, and seed officers from DAO.

Table 1. Composition and number of participants of FGD.

\begin{tabular}{|l|c|c|c|c|c|}
\hline Participants & Cirebon & Brebes & Bantul & Nganjuk & Sub-total \\
\hline Farmers (seed users) & 6 & 7 & 5 & 8 & 26 \\
\hline Seed growers & 3 & 3 & 2 & 3 & 11 \\
\hline Seed traders & 2 & 2 & 3 & 2 & 9 \\
\hline Seed officers (DAO) & 4 & 2 & 4 & 2 & 12 \\
\hline Total & 15 & 14 & 14 & 15 & 58 \\
\hline
\end{tabular}




\section{Results and Discussions}

\subsection{Results}

\subsubsection{Shallot seed-use at the farmers'level}

Shallot variety used varies among the four study sites. Bima Brebes or Bima Curut is the most popular variety used by farmers in Brebes and Cirebon. Farmers in Bantul prefer to use Biru as the first option and Tiron as the second option. Meanwhile, farmers in Nganjuk seem to have more variety options, such as Super Philip, Baoji, Tajuk, and Batu Ijo.

The amount of required seed ranges between $1-2 \mathrm{t} / \mathrm{ha}$, depending on the bulb size (the bigger the size the heavier). More frequent shallot cultivation per year is shown by farmers in Cirebon and Brebes. The fact that farmers grow shallot 3-4 times in a row in the same field has raised some concerns regarding fastening soil fertility degradation (soil fatigue) and sustaining pest and disease infestations. About $60-80 \%$ seed used is originated from own saved seeds and the rest 20 $40 \%$ is obtained from a purchase from other farmers.

Table 2. Variety, seed requirement, frequency of growing, and seed sources

\begin{tabular}{|l|c|c|c|c|}
\hline \multicolumn{1}{|c|}{$\begin{array}{c}\text { Varieties used } \\
\text { (last 5 years) }\end{array}$} & \multicolumn{1}{|c|}{ Cirebon } & \multicolumn{1}{|c|}{ Brebes } & \multicolumn{1}{c|}{ Bantul } & \multicolumn{1}{|c|}{ Nganjuk } \\
\cline { 2 - 5 } & Bima Brebes & $\begin{array}{l}\text { Tima Brebes } \\
\text { Kuning }\end{array}$ & $\begin{array}{l}\text { Super Biru Tiron } \\
\text { Super Philip } \\
\text { Crok Kuning }\end{array}$ & $\begin{array}{l}\text { Super Philip Baoji } \\
\text { Tajuk } \\
\text { Batu Ijo }\end{array}$ \\
\hline Seed requirement (t/ha) & $1.5-2.0$ & $1.3-1.8$ & $1.2-2.0$ & $1.0-2.0$ \\
\hline Freq. of grow (times/year) & $2-3$ & $2-4$ & $1-2$ & $1-2$ \\
\hline Seed sources: & & & & $80 \%$ \\
\hline Own saved seeds & $65 \%$ & $70 \%$ & $60 \%$ & $17 \%$ \\
\hline Other farmers & $32 \%$ & $28 \%$ & $38 \%$ & $3 \%$ \\
\hline Seed growers & $1 \%$ & $1 \%$ & $0 \%$ & $0 \%$ \\
\hline Agro-shop & $2 \%$ & $1 \%$ & $2 \%$ & $8 \%$ \\
\hline
\end{tabular}

Rank of importance of factors affecting variety selection inclines to be considered similarly by farmers in the four study sites. All sites suggest that high yield potential or productivity is considered as the first most important factor influencing farmers in selecting a certain variety. Farmers consider year-after-year yield stability as the second most important factor. In all study sites, farmers are always concerned with the risk of pest/disease infestation and the possible occurrence of water shortage. This may explain why farmers consider environmental adaptability as the third most important factor affecting variety selection. Table 3 also shown that farmers consider the variety agronomic traits (productivity/high yield potential, yield stability, environmental adaptability) as factors of higher importance in selecting a certain variety than the variety non-agronomic attributes (seed price, market demand and recommendations). 
Table 3. Importance of factors affecting farmers in variety selection

\begin{tabular}{|c|l|c|c|c|c|c|c|c|c|}
\hline \multirow{2}{*}{ No. } & \multirow{2}{*}{ Factors } & \multicolumn{2}{c|}{ Cirebon } & \multicolumn{2}{c|}{ Brebes } & \multicolumn{2}{c|}{ Bantul } & \multicolumn{2}{c|}{ Nganjuk } \\
\cline { 3 - 10 } & & RI & AVI & RI & AVI & RI & AVI & RI & AVI \\
\hline 1 & Affordable seed price & V & 4.2333 & VI & 3.9333 & IV & 3.8667 & VI & 3.3000 \\
\hline 2 & Productivity/high yield & I & 4.5333 & I & 4.3000 & I & 4.3333 & I & 4.3667 \\
\hline 3 & Market demand & IV & 4.2667 & IV & 4.1000 & V & 3.8333 & III & 4.1000 \\
\hline 4 & Only variety available & VIII & 3.3333 & IX & 3.0333 & IX & 2.9565 & VIII & 2.7667 \\
\hline 5 & Yield stability & III & 4.2667 & II & 4.1333 & II & 4.2667 & II & 4.1333 \\
\hline 6 & Envir. adaptability & II & 4.3333 & III & 4.1333 & III & 4.2273 & IV & 4.0667 \\
\hline 7 & High farm-gate price & VI & 4.1333 & V & 4.0333 & VI & 3.8333 & V & 3.8667 \\
\hline 8 & Seed seller recomm. & IX & 3.3000 & X & 2.9333 & X & 2.8000 & IX & 2.7333 \\
\hline 9 & Ext./govern. recomm. & X & 3.2667 & VII & 3.3000 & VIII & 3.1333 & X & 2.6667 \\
\hline 10 & Oth. farmers recomm, & VII & 3.4000 & VIII & 3.2000 & VII & 3.3333 & VII & 2.9667 \\
\hline
\end{tabular}

$\mathrm{RI}=$ Rank of Importance

AVI $=$ Average Value of Importance

As many as one-third of farmers procure the seeds by purchasing them from other farmers. The most important factor considered by farmers in purchasing the seeds is seed availability at planting time, followed by expected yield, seed healthiness, and physiological age of seeds. Meanwhile, seed variety, seed price and source of seeds are considered as of lower importance.

Table 4. Importance of factors affecting farmers in purchasing seeds

\begin{tabular}{|l|c|c|c|c|c|c|c|c|}
\hline \multirow{2}{*}{ Factors } & \multicolumn{2}{c|}{ Cirebon } & \multicolumn{2}{c|}{ Brebes } & \multicolumn{2}{c|}{ Bantul } & \multicolumn{2}{c|}{ Nganjuk } \\
\cline { 2 - 9 } & RI & AVI & RI & AVI & RI & AVI & RI & AVI \\
\hline Physiological age of seeds & IV & 4.2667 & III & 4.0333 & III & 3.7000 & IV & 3.3000 \\
\hline Expected high yield & II & 4.6667 & II & 4.4000 & II & 4.1000 & II & 4.3000 \\
\hline Availability at planting time & I & 4.7667 & I & 4.4667 & I & 4.2667 & I & 4.5000 \\
\hline Seed health & III & 4.4000 & IV & 3.9333 & IV & 3.4333 & III & 3.7333 \\
\hline Origin/source of the seed & VII & 3.0333 & VII & 3.0000 & VII & 2.7000 & VI & 2.8667 \\
\hline Seed variety & V & 3.5333 & VI & 3.1667 & VI & 2.9667 & VII & 2.8667 \\
\hline Seed market price & VI & 3.4333 & V & 3.3000 & V & 3.1333 & V & 3.1000 \\
\hline
\end{tabular}

$\mathrm{RI}=$ Rank of Importance

$\mathrm{AVI}=$ Average Value of Importance

Most participants are in agreement that (a) quality and yield of seeds supplied by the existing system are still relatively low, (b) limited availability of clean and healthy seeds, (c) seeds available in the market have no quality assurance, (d) lack of qualified human resources supporting the seed system, (e) lack of seed supporting facilities and infrastructures, and (f) lack of seed production technology transfer. 
Table 5. Participants' general opinions regarding the existing seed system

\begin{tabular}{|l|l|l|l|l|l|l|l|}
\hline & \multicolumn{2}{|l|}{ Cirebon (15) } & \multicolumn{2}{|l|}{ Brebes (14) } & \multicolumn{2}{|l|}{ Bantul (14) } & \multicolumn{2}{|l|}{ Aganjuk (15) } \\
\hline \begin{tabular}{|l|l|l} 
Agree \\
$(\%)$
\end{tabular} & $\begin{array}{c}\text { Disagree } \\
(\%)\end{array}$ & $\begin{array}{l}\text { Agree } \\
(\%)\end{array}$ & $\begin{array}{c}\text { Disagree } \\
(\%)\end{array}$ & $\begin{array}{l}\text { Agree } \\
(\%)\end{array}$ & $\begin{array}{l}\text { Disagree } \\
(\%)\end{array}$ & $\begin{array}{l}\text { Agree } \\
(\%)\end{array}$ & $\begin{array}{l}\text { Disagree } \\
(\%)\end{array}$ \\
\hline
\end{tabular}

- Bulb seeds supplied by the existing system are still sub-optimal in quality and yield

\begin{tabular}{|c|c|c|c|c|c|c|}
\hline \multicolumn{2}{|c|}{ 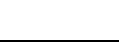 } & 73.3 & 26.7 & \multicolumn{2}{|c|}{143} & \begin{tabular}{l|l}
.1 & 73.3
\end{tabular} \\
\hline
\end{tabular}

- Clean and healthy shallot bulb seeds used by farmers and seed growers are still limited

\begin{tabular}{l|l|l|l|l|l|l|l|l|}
\hline & 93.3 & 6.7 & 92.9 & 7.1 & 100.0 & 0 & 85.7 & 14.3 \\
\hline
\end{tabular}

- There is no quality assurance for shallot bulb seeds available in the market

\begin{tabular}{l|l|l|l|l|l|l|l|l|}
\hline & 93.3 & 6.7 & 100.0 & 0 & 100.0 & 0 & 80.0 & 20.0 \\
\hline
\end{tabular}

- Seed system has not been sufficiently supported by qualified human resources

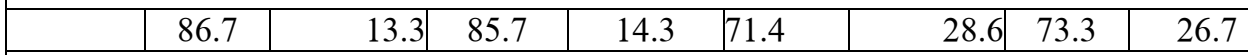

- Lack of supporting infra-structure and facilities, especially for seed testing and storage

\begin{tabular}{|l|l|l|l|l|l|r|r|r|}
\hline & 86.7 & 13.3 & 85.7 & 14.3 & 71.4 & 28.6 & 80.0 & 20.0 \\
\hline
\end{tabular}

- Lack of seed production transfer technology both to farmers and seed growers

\begin{tabular}{|l|l|l|l|l|l|l|l|}
\hline 93.3 & 6.7 & 92.9 & 7.1 & 92.9 & 7.1 & 73.3 & 26.7 \\
\hline
\end{tabular}

\subsubsection{Shallot seed formal system}

The formal system is a government supported system to produce and distribute seed through officially regulated mechanism. This system is mainly guided by plant breeding scientific methodologies. The seed multiplication may be operated and controlled by public and/or private sector specialists. The system is distinguished by public sector regulated-components, typically by a process of inspection for seed certification. The inspection also includes management over variety release, to make certain that available seed is derived from an admitted variety and with a minor occurrence of diseases [30,31]. In Indonesia, the major actors of the shallot formal system are several public institutions under the coordination of the Ministry of Agriculture (MOA) Directorate General of Horticulture (DG Horticulture) and the Indonesian Agency for Agricultural Research and Development (IAARD). The formal system consists of institutional components that have well-defined roles and responsibilities to produce certified seeds for farmers. An official catalog of seeds and varieties has to previously register the seeds. The certified label warrants that the seed meets the standards and minimum requirements of the official seed certifying agency. The flow of seed from breeder seed to extension seed is as follow.

Table 6. Flow chart of the shallot formal seed system in Indonesia

\begin{tabular}{|l|l|}
\hline \multicolumn{1}{|c|}{ Variety } & $\begin{array}{l}\text { released by the Indonesian Vegetable Research Institute } \\
\text { (IVEGRI) or the Assessment Institute for Agricultural } \\
\text { Technology (AIAT) at provincial level }\end{array}$ \\
\hline Breeder seed (BS) & produced by IVEGRI or AIAT's \\
\hline $\begin{array}{l}\text { Foundation seed } \\
\text { (FS) }\end{array}$ & $\begin{array}{l}\text { produced by AIAT's or Provincial Horticultural Seed } \\
\text { Production Unit or Seed Grower accompanied by breeders; } \\
\text { supervised by the Horticultural Seed Certification and } \\
\text { Inspection Office (HSCIO) }\end{array}$ \\
\hline Stock seed (SS) & $\begin{array}{l}\text { produced by AIAT's or Provincial Horticultural Seed } \\
\text { Production Unit or Seed Growers; supervised by the HSCIO }\end{array}$ \\
\hline $\begin{array}{l}\text { Extension seed } \\
\text { (ES) }\end{array}$ & $\begin{array}{l}\text { produced by AIAT's or Provincial Horticultural Seed } \\
\text { Production Unit or Seed Growers; supervised by the HSCIO }\end{array}$ \\
\hline $\begin{array}{l}\text { Seed distribution } \\
\text { and sales }\end{array}$ & $\begin{array}{l}\text { carried out by AIAT's or Provincial Horticultural Seed } \\
\text { Production Unit or Seed Growers }\end{array}$ \\
\hline
\end{tabular}


Technical Guidance for Certification is also arranged to guide seed officer/ supervisor and seed quality assurance for carrying out seed certification properly and correctly, so that quality shallot seeds are obtained in compliance with the applied requirements.

Table 7. Minimum requirements for shallot bulb seeds

\begin{tabular}{|c|c|c|c|c|c|c|}
\hline \multirow[b]{2}{*}{ No. } & \multirow[b]{2}{*}{ Parameter } & \multirow[b]{2}{*}{ Unit } & \multirow[b]{2}{*}{ BS } & \multicolumn{2}{|c|}{ Seed Class } & \multirow[b]{2}{*}{ ES } \\
\hline & & & & FS & SS & \\
\hline \multirow[t]{10}{*}{1.} & Field & & & & & \\
\hline & a. Mixed varieties and irregularities, max. & $\%$ & 0.0 & 0.0 & 1.0 & 1.0 \\
\hline & b. Plant health & & & & & \\
\hline & $\begin{array}{l}\text { Number of plants infected by pests and diseases, } \\
\text { max. }\end{array}$ & & & & & \\
\hline & Viruses & $\%$ & 0.0 & 0.2 & 1.0 & 1.0 \\
\hline & $\begin{array}{ll}\text { - } & \text { Onion Yellow Dwarf Virus }(O Y D V) \\
\text { - } & \text { Shallot Latent Virus }(S L V) \\
\text { - } & \text { Leak YellowStripe Virus (LYSV) }\end{array}$ & & & & & \\
\hline & Fungals & & & & & \\
\hline & - $\quad$ Altenaria porii & $\%$ & 0.2 & 0.5 & 0.5 & 0.5 \\
\hline & - Peronospora destructor & $\%$ & 0.0 & 1.0 & 1.0 & 1.0 \\
\hline & c. $\quad$ Field management & \multicolumn{5}{|c|}{$\begin{array}{l}\text { Field inspection is stopped when ther } \\
\text { are uncontrolled weeds as host of } \\
\text { pests/ diseases and virus vector } \\
\text { - Field inspection is stopped when ther } \\
\text { are serious mechanical/insect damage } \\
\text { on leaves, and poor plant growth }\end{array}$} \\
\hline 2. & Bulb quality & & & & & \\
\hline & a. Mixed varieties and irregularities, max. & $\%$ & 0.0 & 0.2 & 0.5 & 1.0 \\
\hline & b. Plant health & & & & & \\
\hline & Fungals & $\%$ & 0.5 & 1.0 & 2.0 & 3.0 \\
\hline & $\begin{array}{ll}\text { - } & \text { Botrytis allii } \\
\text { - } & \text { Alternaria porii } \\
\text { - } & \text { Colletotricum gloeosporioides } \\
\end{array}$ & & & & & \\
\hline & Bacterial & & & & & \\
\hline & - Erwinia arotovara & $\%$ & 0.2 & 0.5 & 1.0 & 2.0 \\
\hline & Mechanical damage & $\%$ & 0.5 & 1.0 & 2.0 & 3.0 \\
\hline
\end{tabular}

Even though, the formal system had been established more than a decade ago, FGDs suggest that in general, the system has not developed well as expected. Insignificant share of this system to the shallot industry is indicated by the estimated low number of active certified seed growers and low seed production capacity per year in the four study sites. FGDs have identified some factors that may cause the slow development of the formal system. Certified seed growers indicate some limiting factors, such as the difficulty in estimating or projecting seed demand, lack of varieties released by breeding component of the system that are preferred by farmers, the difficulty to satisfy minimum requirement of certification, especially to control pests and diseases damage intensity as low as $0.5-3.0 \%$, low demand of certified seeds from users, unavailability of large storage for storing the seeds, and tight and thorough selection during harvest and storage that are very labor-intensive and costly. Based on these challenges, most seed growers still perceive that growing certified seeds is a risky business. Most seed growers even suggest that they are willing to produce the seed only if there is government program/project that provides guarantee of buying the seeds. In the meantime, from farmers' or users' perspective, some issues that may contribute to the slow development of formal system are also raised, such as the rarity of buying seeds because they use own saved seeds, lack of certified seed promotion, and perception that certified seeds are more expensive with no guarantee of having higher yield as compared to non-certified seeds. 
Table 8. Estimated number of certified seed growers and their production capacity

\begin{tabular}{|c|l|l|c|c|c|}
\hline & & Cirebon & Brebes & Bantul & Nganjuk \\
\hline 1 & Seed production method & $\begin{array}{l}\text { Following Standard Operating Procedure issued by } \\
\text { DG Hort }\end{array}$ \\
\hline 2 & $\begin{array}{l}\text { Estimated number of active } \\
\text { Inspected and certified by the Horticultural Seed } \\
\text { Certification and Inspection Office }\end{array}$ & 2 & 4 & 3 & 5 \\
\hline 3 & $\begin{array}{l}\text { Estimated seed production } \\
\text { capacity per } \\
\text { year }\end{array}$ & $25-30 \mathrm{t}$ & $40-50 \mathrm{t}$ & $30-35 \mathrm{t}$ & $40-50 \mathrm{t}$ \\
\hline
\end{tabular}

Out of the four study sites, Nganjuk-East Java has a shallot formal seed system that performs the best. It was recorded that during the period of 2009-2014, formal shallot seed system in Nganjuk-East Java had produced about $604 \mathrm{t}$ of certified shallot seed [32]. Latest data from the East Java Horticultural Seed Certification and Inspection Office indicate that for 2020 (until July), East Java seed growers (including Nganjuk) have produced a total of 792,4 t of certified seeds consisting of Batu Ijo (119 t), Bauji (65 t), Bima Brebes (123.9 t), Super Philip (36 t), and Tajuk (449.5 t).

\subsubsection{The shallot informal seed system}

The informal system is complex and conceptually less clear in that it facilitates a farmer to save seed from harvest, exchange seed among farmers or buy seed from local markets. This system also allows a farmer to sell his/her excess harvest to other farmers as seed. Informal seed systems are the most important seed source, especially for small-scale farmers in many developing countries $[33,34]$.

In Indonesia, the shallot seed supply by the informal system reflects its importance in national shallot seed security. About $70-80 \%$ of shallot seed used by Indonesian smallholder farmers is saved and exchanged seeds, and the remaining $19-29 \%$ is seed bought in local markets. The informal seed system accounts for $99 \%$ of the seed used by smallholder farmers [32], while the share of improved or certified seed is about $1 \%$. FGDs suggest that the heavy reliance of majority shallot farmers on the informal shallot seed system is due to some key reasons as follow (a) the seeds coming from informal system are relatively more affordable and available at the time needed, (b) the system allows farmers to observe the shallot seed crop production in the field before deciding to buy, and (c) as compared to the formal system, farmers perceive that the system is more reliable and sustainable.

Saving the produce from their previous harvest is the simplest way for farmers to acquire shallot seeds. FGDs suggest that by doing so, farmers may have more control to the seeds and become more knowledgeable based on own experience about the plant's traits embodied in the seeds. Using own saved seeds means the farmers are able to obtain the shallot seeds on time and they do not have to procure seeds from other exchange transactions. However, farmers sometimes have to get the seeds from external sources, especially when they experience seed loss. Seed loss occurred because of a variety of factors identified in FGDs, including crop failure, poor yield that forces farmers to sell all of the harvest to meet household needs, and selling all of the harvest when the price of shallot bulb consumption is exceptionally high. FGDs also indicate that sourcing shallot seeds from neighboring farmers will cost farmers less, since the seed information is easily gathered and the seed growing conditions are often better known. Furthermore, FGDs also reveal the importance of and how well farmers are adapted to the existing informal shallot seed system. 
Table 9. Importance of informal seed system in the four study sites

\begin{tabular}{|c|c|c|c|c|}
\hline & Cirebon (\%) & Brebes (\%) & Bantul (\%) & Nganjuk (\%) \\
\hline \multicolumn{5}{|l|}{ Seed used in last planting season } \\
\hline \begin{tabular}{l|l} 
Non-certified seed \\
\end{tabular} & 99.0 & 99.0 & 100.0 & 97.0 \\
\hline Certified seed & 1.0 & 1.0 & 0.0 & 3.0 \\
\hline \multicolumn{5}{|l|}{ Seed used for next planting season } \\
\hline Own saved seed & 43.3 & 80.0 & 60.0 & 96.7 \\
\hline Purchased from other farmers & 43.3 & 16.7 & 26.7 & 3.3 \\
\hline Both & 13.3 & 3.3 & 13.3 & 0.0 \\
\hline \multicolumn{5}{|l|}{ When using saved seed } \\
\hline $\begin{array}{l}\text { Selection carried out since the crops } \\
\text { are still in the field - plant growth } \\
\text { and healthiness }\end{array}$ & 33.3 & 66.7 & 43.3 & 46.7 \\
\hline $\begin{array}{l}\text { Selection carried out after harvest - } \\
\text { tuber appearance }\end{array}$ & 66.7 & 30.0 & 50.0 & 36.7 \\
\hline Both & 0.0 & 3.3 & 6.7 & 16.7 \\
\hline \multicolumn{5}{|l|}{ Form of purchased seed } \\
\hline Tuber or bulb seeds & 86.7 & 66.7 & 83.3 & 100.0 \\
\hline Seed candidates & 13.3 & 33.3 & 16.7 & 0.0 \\
\hline \multicolumn{5}{|l|}{ When using purchased seed } \\
\hline $\begin{array}{l}\text { Evaluation started out since the crops } \\
\text { are still in the field - plant growth } \\
\text { and healthiness }\end{array}$ & 3.3 & 16.7 & 26.7 & 16.7 \\
\hline $\begin{array}{l}\text { Evaluation carried out before buying } \\
\text {-tuber seed appearance }\end{array}$ & 96.7 & 80.0 & 73.3 & 83.3 \\
\hline Both & 0.0 & 3.3 & 0.0 & 0.0 \\
\hline
\end{tabular}

\subsection{Discussions}

Despite the all-round support provided by the government, the formal shallot seed system is not yet developed to the level it should attain. The formal system is theoretically capable of producing markedly better seed for shallot production, because it is a purposely designed and restricted system requiring a chain of activities leading to clear outputs, i.e. certified seed of checked varieties of optimal physical, physiological, and sanitary quality. However, the success depends to a large extent on the connection effectiveness between components in the system. For example, the lack of high yielding shallot varieties released and offered by IVEGRI or AIATs may contribute as one of the reasons why farmers less interested in acquiring certified seeds. Farmers are most likely to purchase certified seeds when they can provide higher yield than farm-saved seed. When seed development is poorly organized in each component and has resulted in low quality seeds, the coordinated relations between components may also break. If the distribution system fails and the seeds do not meet farmers in the correct quality and quantity at the right time and price, the low trust of farmers in the formal system is inevitable. In the case of shallot, better promotional efforts and proven field evidences appear urgently needed to convince farmers the advantages of using certified seeds. Inefficiency of one component will automatically provide negative effects to the performances of other components in the system. Hence, the interdependence of the different components remains a challenge for the organization of a formal shallot seed system to succeed.

In the meantime, in informal seed systems, farmers mostly carry out all of the activities that include producing, disseminating, and accessing the seeds through saving own production; exchanging with other farmers; and procuring seed candidates from other farmers' shallot cultivation. As the main source of shallot seeds, although it has been shown to be logical and complex, and has a high degree of versatility, this mechanism is also not free from weaknesses. Farmers may be poorly prepared for shortages, when seed is commonly readily available. Severe drought and pests/diseases infestation, and basically the inability to put seed aside from the harvest may cause an acute problem with seed security of shallot farmers. Plenty of seed is 
available when farmers have a productive shallot season. Since most farmers have more flexibility in combining own saving seed with their consumption needs, the demand for seed among farmers and on local markets will be low. However, after a poor shallot season, seed availability is usually low and demand for seed is likely to be high. When contacts with other areas that experience better cropping season are limited, over-all seed shortages is most likely to occur. This condition may force farmers to rely on poor quality materials, such as those available in the local market with unknown seed characteristics.

In informal system, it is common that the seed production is a part of normal shallot crop production. While most farmers apply similar seed selection criteria for the next planting, the degree of specialization varies greatly and has led to a high variance in the quality of seeds. Despite the extensive local knowledge base of communities that depend on their own saved seeds, there remains a certain level of local ignorance as well. In seed related issues this may translate into low seed health and high risk of severe disease epidemics to occur. In addition, the seed shortage that leads to an unrealistically high price of seeds is often happened lately because of farmers' temptation to sell all of their harvest, when the price of shallot bulb consumption is exceptionally high.

Both structures have their own advantages and disadvantages. Both formal and informal seed systems must be included in a strengthened program designed to establish a shallot seed system that can supply the seeds at the right time, with the correct amount, quality and affordability. The seed system improvements should recognize the coexistence of different seed systems, next to each other, and promotes the support of each system, building on its particular advantages and disadvantages. In the formal system, the breeding capacity of IVEGRI/AIATs in generating high yielding shallot varieties preferred by farmers should be strengthened. This implies putting more resources to the revitalization of participatory breeding approach that treats farmers not just as clients, but more of partners. The implementation of standard for seeds called Quality Declared Seed - QDS [35] may also be a useful option to bridge the gaps in seed quality management procedures between formal and informal system. In order to accommodate the majority of established seed systems and to consider the variety of seed use, it is likely that QDS will improve the quality of seeds available to farmers and strengthen local seed companies by reducing the burden of complete certification. Farmers' seed management practices in the seed production of informal system should be continuously improved through extension activities and linkages to IVEGRI/and AIATs and other centers for the advancement of seed technology. Interventions to improve understanding of the management of seed pest and diseases and to solidify seed storage practices can contribute to preserving the quality of seeds at the household level. Other shallot yield improved technologies are also needed to increase yield, reduce seed loss risk, and mitigate the effect of anti-cyclic nature of seed availability. The initiatives should therefore go beyond the seed aspects to cover all facets of shallot best practices.

\section{Conclusion}

Simply improving the interdependence of the different components in shallot formal seed system ignores the importance of the other systems, in supplying smallholder farmers with quality seed, and as such may put farmers' seed security at risk. But also, focusing on only strengthening the shallot informal seed system, does not answer the issue of increasing shallot production and competitiveness. Both systems actually have considerable strengths that need to be leveraged more systematically. Therefore, integrating and recognizing the coexistence of the formal and informal seed systems in the four shallot producing areas in Java should be embraced to optimize the mutual benefits between the two systems.

\section{References}

1. S. Harper, D. McGrath, J. Thomas. Scoping study report on vegetable production in highland and lowland areas of Java Indonesia, ACIAR SRA (2010). 
2. K. Kusena, R. Wynberg, C. Mujaju. Do smallholder farmer-led seed systems have the capacity to supply good-quality, fungal-free sorghum seed? Agric \& Food Secur. 6, 52 (2017).

3. F. Beyene. The role of NGO in informal seed production and dissemination: The case of eastern Ethiop. J of Agric. and Rur. Devel. in the Tropics and Subtropics, 111, 2 (2010).

4. M.G. Mula. Seed delivery system: The key for a sustainable pulse agriculture for smallholder farmers. Green Farming Strategic Vision 12, Green Farming J. 3, 6 (2012).

5. T. Nurasa, V. Darwis. Analisis usahatani dan keragaan marjin pemasaran bawang merah di Kabupaten Brebes, Akta Agrosia, 10, 1 (2010).

6. S. Simatupang, T. Sipahutar, \& Sutanto. Kajian usahatani bawang merah dengan paket teknologi good agriculture practices', J. Pengkajian dan Pengemb. Tek. Pert. 20, 1 (2017).

7. M.J. Paul, A. Watson, C.A. Griffiths. Linking fundamental science to crop improvement through understanding source and sink traits and their integration for yield enhancement $\mathrm{J}$. of Exp. Bot. 71, 7 (2020).

8. R. Gajbhiye, MS. Nain, P. Singh, S.K. Dubey, J.P. Sharma. Comparative assessment of seed delivery system in Patiala District of Punjab, J. of Comm. Mobil. \& Sust. Dev., 9, 2 (2014).

9. H. Chand, B. KC. Quality seeds for food security and food self -sufficiency during havoc of Covid-19 in Nepal, Trop. Agroecos. (TAEC), 1, 2 (2020).

10. G. Abebe, A. Alemu. Role of improved seeds towards improving livelihood and food security at Ethiop, Int. J. of Res.-Granthaalayah, 5, 2 (2017).

11. F.B. Mihretu. Challenges and opportunities of vegetable quality seed production and seed system in Ethiopia, International J. of Res. Stu. in Agric. Sci., 5, 8 (2019).

12. W.E. Finch-Savage, G.W. Bassel. Seed vigour and crop establishment: extending performance beyond adaptation, J. of Exp. Bot., 67, 3 (2016).

13. G.E. Sabry. The importance of using high quality seeds in agriculture systems. Agric. Res. \& Tech. Open Access J., 15, 4 (2018).

14. M.G. Mula. Seed system institutionalization for pulses: A must in the Philippines, A paper presented during the 1st Philippine Pigeonpea Congress', 16-18 December 2014, Mariano Marcos State University (MMSU), Batac, Ilocos Norte, Philippines (2014).

15. M. Sheahan, C.B. Barrett. Ten striking facts about agricultural input use in Sub- Saharan Africa, Food Policy, 67 (2017).

16. B.S. Tomar, Kalyanrao, K.V. Kumar, Seed production: An entrepreneurial venture, Indian Farming, 61, 4 (2011).

17. S. Rajendrana, V. Afari-Sefa, D.K. Karanjac, R., Musebed, D. Romneye, M.A. Makaranga, S. Samalig, R.F. Kessyh. Farmer-led seed enterprise: Initiatives to access certified seed for traditional African vegetables and its effect on incomes in Tanzania, Int. Food and Agrib. Manag. Rev., 19, 1 (2016).

18. A. Atilaw, D. Alemu, Z. Bishaw, T. Kifle, K. Kaske. Early generation seed production and supply in Ethiopia - Status, challenges and opportunities, Ethiop. J. Agric. Sci., 27, 1 (2017).

19. K. Alemu. Seed production and dissemination systems analyses: The case of Ethiopia, Food Sci. \& Qual. Manag., 35 (2015).

20. A.G. Poku, R. Birner, S. Gupta. Why do maize farmers in Ghana have a limited choice of improved seed varieties? An assessment of the governance challenges in seed supply, Food Security, 10 (2018).

21. K. Kusse, K. Kebede. Access, supply system and utilization of improved seed varieties in Debub Omo Zone, SNNPR, Ethiop. J. Agri. Sci. Food Res. 10 (2019).

22. R.M. Dilshad, M.I. Latif. Focus group interview as a tool for qualitative research: An analysis, Pakistan J. of Soc. Sci. (PJSS), 33, 1 (2013).

23. A. Beigzadeh, K. Bahaadinbeigy, P. Adibi, N. Yamani. Identifying the challenges to good 
clinical rounds: A focus-group study of medical teachers J. Adv. Med. Educ. Prof. 7, 2 (2019).

24. A.E.Buijs, A. Fischer, D. Rink, J.C.Young. Looking beyond superficial knowledge gaps: Understanding public representations of biodiversity. Int. J. of Biodiv. Sci. and Manag., 4 (2010).

25. V. Wibeck. Images of environmental management: Competing metaphors in focus group discussions of Swedish environmental quality objectives. Envir. Manag., 49 (2011).

26. R.P. Harisha \& S. Padmavathy. Knowledge and use of wild edible plants in two communities in Malai Madeshwara Hills, Southern India. Internat. J. of Botany, 9 (2013).

27. R. Kraaijvangera, C.J.M. Almekindersc, A. Veldkampd. Identifying crop productivity constraints and opportunities using focus group discussions: A case study with farmers from Tigray, NJAS -Wageningen J. of Life Sci., 78 (2016).

28. N. Greenwood, T. Ellmers, J. Holley. The influence of ethnic group composition on focus group discussions, BMC Med. Res. Meth., 14, 107 (2014).

29. T.O Nyumba, K. Wilson, C.J. Derrick, N. Mukherjee. The use of focus group discussion methodology - Insights from two decades of application in conservation. Meth. Ecol Evol., 9 (2018).

30. N. P. Louwaars, W.S. de Boef. Integrated seed sector development in Africa: A conceptual framework for creating coherence between practices, programs, and policies. J. of Crop Improv., 26, 1 (2012).

31. ICARDA. Strengthening national seed systems for household food security in developing countries. International Center for Agricultural Research in the Dry Areas, PO Box 114/5055, Beirut, Lebanon (2015).

32. Baswarsiati, T. Sudaryono, K.B. Andri, S. Purnomo. Pengembangan varietas bawang merah potensial dari Jawa Timur. Dalam: Djatnika, M. Jawal dan D. Widiastoety. Editor. Inovasi Hortikultura Pengungkit Peningkatan Pendapatan Rakyat. Badan Penelitian dan Pengembangan Pertanian. IAARD Press (2015).

33. T.B. Gill, R. Bates, A. Bicksler, R. Burnette, V. Ricciardi, L. Yoder. , L. Strengthening informal seed systems to enhance food security in Southeast Asia. J. of Agric. Food Syst. and Comm. Devel., 3(3), 139-153 (2013).

34. S. McGuire, L. Sperling. Seed systems smallholder farmers use. Food Sec. 8 (2016).

35. R.P. Singh, R.C. Agrawal. Improving efficiency of seed system by appropriating farmer's rights in India through adoption and implementation of policy of quality declared seed schemes in parallel, MOJ Eco Environ Sci. 3, 6 (2018). 